\title{
An Employer Survey on Industrial Sector Involvement in Malaysian National Dual Training System
}

\author{
Baba Md Deros ${ }^{1}$, Suzana Mohammed Zohdi ${ }^{1}$, Darliana Mohamad $^{1}$, Nor Kamaliana Khamis ${ }^{1} \&$ Nizaroyani \\ Saibani $^{1}$ \\ ${ }^{1}$ Department of Mechanical and Materials Engineering, Faculty of Engineering \& Built Environment, Universiti \\ Kebangsaan Malaysia, Selangor, Malaysia \\ Correspondence: Baba Md Deros, Department of Mechanical and Materials Engineering, Faculty of Engineering \\ \& Built Environment, Universiti Kebangsaan Malaysia, 43600 UKM Bangi, Selangor, Malaysia. Tel: \\ 60-3-8921-6117. E-mail:hjbaba@eng.ukm.my
}

\author{
Received: October 5, 2012 Accepted: November 23, 2012 Online Published: November 30, 2012 \\ doi:10.5539/ass.v8n16p232 URL: http://dx.doi.org/10.5539/ass.v8n16p232
}

\begin{abstract}
The main purpose of this survey is to get industrial employers' feedback on the reasons for their lack of involvement in National Dual Training System (NDTS) organized by the Department of Skills Development, Ministry of Human Resources Malaysia. Industrial employers' involvement and support is very important in ensuring NDTS implementation success. Therefore, it is very critical to identify factors and barriers that hinder industrial sectors from participating in NDTS program. A survey questionnaire was developed to act as a data collection instrument. Survey questionnaire was sent to 5,000 companies comprising of multinationals, small and medium-sized industries. However, only 509 companies returned the completed questionnaires giving a low response rate of $10.18 \%$. Survey results revealed the following factors hinders industrial sectors from participating in NDTS program; they are: training culture, organizational structure, financial and physical resources, policies, NDTS awareness, employer's commitment and technological factors. In addition, survey result showed respondents companies have good training culture; however, they tend to focus on-the-job training. Majority of respondents did not participate in the NDTS because they were not aware about its existence and no information or publicity materials made available to them. Therefore, the authors strongly suggest the Department of Skills Development, Ministry of Human Resources Malaysia to enhance their promotion and publicity campaign on NDTS program to industrial sectors.
\end{abstract}

Keywords: feedback, industry, involvement, national, training, skills, survey

\section{Introduction}

In Malaysia, vocational education in secondary schools and skill training institutes is very common. Vocational education operates mainly through school-based programs in vocational schools and skill training institutes with very little related to work experience or direct involvement of industrial employers. Very often, schools and skill training institutes offers general practical or hands-on experience in the workshops with minimal connection to the relevant occupational program. In other words, apprenticeship training in plays only a minor role in the qualification and credentialing of employees for careers in the intermediate sector.

\section{Background of Problem}

Rapid industrial development results in high demand towards skill workers. Industrial development in globalization era requires skill workers to maintain the country and global competitiveness. A study by Economic Planning Unit (2008) found that 136 thousand youngsters join the work force every year without having any skill or advanced education. In short, Malaysian government decision to establish and implement NTDS is an excellence step towards producing $K$-Workers for solving rapid and complex technological change (Department for skill development, 2008a). However, results from many past studies shows that majority of small and medium enterprises employers' were not very committed to apprenticeship training, except multinational and large companies. The question is, how to implement NDTS successfully according to plan, if the commitment from employers' is low (Wan Seman, 2007). Therefore, we need to find the answer with respect to employer's commitment towards apprentice training programme. The identified organization and technological factors need to be further investigated which may contributes towards the low commitment. 
Therefore, a comprehensive study needs to be implemented to find out the true picture of industrial participation in NTDS to help the nation producing quality $K$-Workers.

\section{Apprenticeship System Concept}

The main objective of an apprenticeship system is to prepare skilled and human resource embedded with the required and relevant characteristics to work in industries. This apprenticeship system involves both the employers and apprentice. It is hoped by implementing apprenticeship system would reduce the mismatched between the current skilled human resource demands and supply because it would be able to provide real industrial work exposure to young apprentice.

In Germany, the apprenticeship system integrates both training procedures in vocational institutions and hands-on training in actual work environment (Deissinger et al., 2011; Deissinger 2007; 1996). This is in-line with Steedman (1998) findings that many German firms have very high proportion of the workforce having intermediate level qualifications. The dual vocational training system functions as initial training for school leavers in a given range of recognised and holistic training occupational qualifications (Deissinger, 2000). In short, this dual training system prepare graduate to acquire work experience and vocational qualification in two different situations. Besides the state, public, private and semi-private institutions must work together by using long-established modes of cooperation within the system (Deissinger, 2007). Similar training system is widely practiced in Austria and France (Deissinger et al., 2011), Switzerland (Pilz, 2007) and in Georgia (Smith, 1997). It provide training to apperentices to equipped them with vocational and technical skills by undergoing training at the institute and industry. However, the main difference that distinguish the German dual system of vocational education and training (VET) from most training systems in the world is the companies voluntary contribution for both practical and financial (Deissinger, 2001). According to Liepman (1960) apparenticeship is concept, characterized by duality of its nature: the apprentice is both learning and earning, the employer is both training $\mathrm{him} / \mathrm{her}$ and paying him/her for productive work. In practice, apprenticeship, forms part of the educational system and part of the economic system and the adequacy of apprenticeship turns largely upon its success in harmonizing the interests of education and the production (Liepman, 1960).

In Germany, dual system training has been successfully implemented for a long period time and enjoys strong support from industrial employers. Schmidt and Alex (1997) explained that the dual system was founded based on close links between public and private training organizations, between statutory provision and provision governed by collective agreements, and between public training policy and private training investment. According to Deissinger (1997), the following characteristics are very important to ensure the dual training system is accepted and supported by German industries, they are:

1) Company participates voluntarily;

2) Standard and training contents are agreed by employers and employees union;

3) Cooperation between employers and employees union at all levels to support the dual training system;

4) Dual training system freedom is safeguards by corporate body or chambers;

5) Dual training system is financed by coporate training provider with sponsorship is provided by the government; and

6) Provide educational opportunities for further education at higher level.

In addition to the aboved stated characteristics, Schmidt and Alex (1997) believed the success of German Dual System were due to:

1) Skilled qualification is highly appreciated in German;

2) White collar and blue collar workers are given high social status in German community;

3) German politicians give high priority to vocational education and training (VET); and

4) There were many researches and developments carried out in institution of higher learning that provide source of imformation database for advice and decision making.

Glover and Bilginsoy (2005) found youth apprentice program was also introduced in United States of America to prepare young American school leavers with appropriate working skills prior to joining the workforce. Glover and Bilginsoy (2005) found 75 percent of apparentice programs are related to electrical field in the construction industry. Meanwhile Stockmann (1997) found in Latin America, apparentice program act as a solution to the lack of skill workers problem in modern work industry. 


\section{Malaysian Apprenticeship System}

The Dual National Training System (NDTS) is an apprenticeship programme. It was first implemented by Department of Skills Development, Ministry of Human Resources Malaysia in 2005. This dual training system involves two different parties, namely: an employer and apprentice. NDTS program is a good effort to establish a closer cooperation between training institutions and industrial employers. An apprenticeship program can form part of the educational and economic system. The adequacy of an apprenticeship programme depends heavily upon its success in harmonizing the educational interests and production system (Liepman 1960). Apprenticeship programme is not new in Malaysia because it has been implemented, since more than 50 years ago. National Apprenticeship Scheme (NAS) was first introduced in Malaysia in 1957 administered by the Central Apprenticeship Board (CAB) (Othman 1992). According to Fong (1986), this scheme is a joint effort by the Malaysian government and industry to meet the nation's requirements for skilled workers. In this scheme, the government provides free training facilities and employers can sponsor their apprentices and provide in-plant training facilities for them.

Since 1973, this scheme was conducted by Lembaga Latihan Perindustrian and Persijilan Ketukangan Kebangsaan (LLPPKK). It was one of the successful systematic training systems based on standard craftsmanship but unfortunately this apprenticeship system was laid off because of insufficient response from employers (Othman 1992). Wan Seman (2007) found the following major barriers towards successful NDTS training implementation, they were: low participation of small and medium-sized enterprises; limited numbers of curriculum developed; and limited numbers of training institutions to cater various training programmes. Organisational and technological factors have been identified as the major contributors to lack of commitment from the employers' side. As a result of this, a comprehensive study needs to be carried out to explore the level of industry participation and identify major reasons for industries lack of involvement in NDTS.

\section{Industry Participation Status in NDTS}

Department of Skill Development was established to take charge of promoting NDTS and incentives to attract more participation from apprentice, industry and training institutes. As a result of these promotional efforts, up till November 2009, 20,463 apprentices from 996 companies have registered to participate in the NDTS focusing in 145 fields in 22 industrial sectors in Malaysia as shown in Table 1 (Department of Skill Development, 2009). Based Malaysia Training Master Plan and Work Skill Development, it is forecasted that NDTS will produce $31,500 \mathrm{~K}$-Workers apprentice and participation from 6,300 companies in this training system by year 2010 (Department of Skill Development, 2009).

Table 1. Classification of skill areas in NDTS according to sectors

\begin{tabular}{clc}
\hline No. & Sectors according to National Occupational Skill Standard (NOSS) & Skill area \\
\hline 1 & Agricultural Base \& Food Industry & 3 \\
2 & Biotechnology & 0 \\
3 & Building \& Constraction & 2 \\
4 & Chemical & 0 \\
5 & Electrical \& Electronic, Telecomunication \& Broadcasting & 9 \\
6 & Banking, Finance \& Insurance & 3 \\
7 & Hospitality \& Tourism & 24 \\
8 & Information Technology \& Comunication & 9 \\
9 & Interior Design & 0 \\
10 & Islamic Studies & 0 \\
11 & Landscape \& Environment & 0 \\
12 & Machining \& Equipment & 27 \\
13 & Materials & 3 \\
14 & Mechanical \& Electrical Maintenance & 3 \\
15 & Medicine \& Pharmaceutical & 14 \\
16 & Others & 1
\end{tabular}


19 Resource Based 3

20 Souvenir \& Small Industry 9

21 Tekstile \& Clothing 6

22 Transportation 26

Total

Based on Malaysia Training Master Plan and Work Skill Development, it is forecasted that NDTS will produce 31,500 k-Workers apprentice and participation from 6,300 companies in this training system by year 2010 (Department of Skill Development, 2009).

\section{Benefits of Implementing NDTS}

To ensure this effort is successful, Double Deduction Income Tax (DDIT) rebate will be given to promote companies participation to sponsor apprentice in NDTS. In addition, for qualified employers they can claim back the training contribution levy from Human Resource Development Berhad. Each apprentice will be paid monthly allowance of between RM350 up to RM500 and good job opportunity to be accepted as permanent employee by the company. Apprentice that successfully completed the NDTS program will be awarded with up to Level 5 Malaysian Skill Certificate (Department of Skill Development, 2007). This national skill training program will benefit the participating companies themselves. Some of the direct benefits to industry as explained in Malaysia Training Master Plan and Work Skill Development 2008 - 2020 (Department of Skill Development, 2007) are: guidelines for recruiting and selecting the appropriate candidates with regards to their respective skills employees; form a basis for fixing the pay and systematic and fairer career advancement; promotes better industrial relations in the workplace by establishing cooperation among employees; assist in evaluating internal training activities and identifying skill training needs; improve product quality and productivity; more competitive and earlier exposure to application new technology.

\section{Methodology}

Two categories of company were involved in this study, they are: Large and Small \& Medium Enterprises. To do this, a survey questionnaire was developed as a data collection instrument used in this study. It comprise of five sections, namely: training culture; organizational structure; resources; policies; and NDTS awareness. Survey questionnaire forms were sent to 5,000 companies from both categories (i.e. 3703 large companies; 1297 Small \& Medium Enterprises) together with a cover letter explaining objectives of the survey by postal mail, electronic mail, facsimile and delivered personally by hand. From the 5,000 survey questionnaire distributed, a total of 509 forms were completed and returned, giving a response rate of 10.18\%. According to Krejcie and Morgan (1970), at this response rate, data collected is adequate to represent the entire population based on the sample sizing method. All data obtained from the completed survey questionnaire forms were analyzed using the Statistical Package for the Social Sciences software (SPSS version 16). Survey instrument validity analysis for each factor was done using Alpha Cronbach. Alpha Cronbach is a reliability index that show the relationship between the items studied. Uma (2000) had the opinion Alpha Cronbach values of 0.7 can be accepted and highly reliable if their values are more than 0.8. In this survey all the factors have Alpha Cronbach values of more than 0.7; therefore, the survey instrument used is reliable.

\section{Survey Results and Discussion}

Qualitative and quantitative analysis were done on the data gathered from respondents based on several factors such as: training culture; organisational structure; resource; policy; and awareness on NDTS. Overall analysis were done on all respondents $(\mathrm{n}=509)$ from all type of companies. The respondents were asked six questions with respect to the company demography, they are: type of ownership; company category; number of employees and respondent's background. Survey results shows $79.6 \%$ of them are locally owned companies; $10.8 \%$ foreign owned companies; and $6.7 \%$ are joint venture companies between local and foreign. In terms of company category, $29.9 \%$ are large companies, $32.6 \%$ small and medium enterprises. Almost $42 \%$ of the respondents comprise of senior managers; followed by $38 \%$ human resource managers; and $20 \%$ chief executive officers (CEOs), managing directors or company owner.

The following organizational factors were included in the survey, they are: training culture, organizational structure, financial resource, policies, NDTS awareness, employer commitment, and work process \& 
technologies. Table 2 shows $67.9 \%$ of respondents' agreed that they have high awareness and implement in-house training program to provide training for their staff to enhance their companies' productivity and competitiveness in the market place. Large majority (78\%) of the companies that took part in the surveyed did not participate on the NDTS program, which quite surprising because $67.9 \%$ of them believe that workers' training is a high priority to their companies.

Table 2. Company Training Priority

\begin{tabular}{lll}
\hline Training as Strategic Factors & Frequency & Percent \\
\hline High & 340 & 67.9 \\
Uncertain & 94 & 18.8 \\
Low & 67 & 13.3 \\
Total & 501 & 100.0
\end{tabular}

In terms of organizational structure, Table 3 shows $45.4 \%$ of respondents' said they have a training section or unit and $55.4 \%$ have a training manager or officer. In general, companies with more than 50 full time workers have a training unit/section and training manager/officer compared to companies with less than 50 workers.

Table 3. Companies with training unit and officer

\begin{tabular}{lccc}
\hline & Yes & No & Uncertain \\
\hline Company had a training section/unit & 45.4 & 48.3 & 6.3 \\
Company had training manager/officer & 55.4 & 41.5 & 3.2 \\
\hline
\end{tabular}

Table 4 shows resources available for employee development. Survey results shows that $63.3 \%$ of respondents have financial resources to pay for their staff training in basic skills, other training and development of human resource. In addition, $73.3 \%$ of respondent companies had identified resources for training implementation in their companies' strategic plan. However, only $65 \%$ of companies have financial allocation to carry out training for basic skill and development to their employees.

Table 4. Resources for employee skill development

\begin{tabular}{lcccc}
\hline & $\begin{array}{c}\text { Yes } \\
(\%)\end{array}$ & $\begin{array}{c}\text { No } \\
(\%)\end{array}$ & $\begin{array}{c}\text { Uncertain } \\
(\%)\end{array}$ & $\begin{array}{c}\text { Total } \\
(\%)\end{array}$ \\
\hline $\begin{array}{l}\text { Provision provided for basic skills training } \\
\begin{array}{l}\text { Company strategic plan identify resources for staff training and } \\
\text { development needs }\end{array}\end{array}$ & 65.0 & 29.1 & 5.9 & 100.0 \\
Provide financial provision for staff development & 63.3 & 5.7 & 21.0 & 100.0 \\
\hline
\end{tabular}

Generally, the aim of policy factor is to investigate related aspect of company policies towards training participation and NDTS. In addition, Table 5 shows the survey had also explored whether; these companies are willing to allow apprentices use their companies' facilities and company policies towards human resource development. From the scores shown in Table 5, it can be concluded that more than $70 \%$ of the companies' policies shows the companies support their employees' participation in training for human resource development. In addition, referring to Table 5 more than $88 \%$ of companies have the view that staff development as important to company success and encourage their employees to study and increase self-ability. However, it is strange that large majority $(82.2 \%)$ of the companies did not participate in the NDTS program. 
Table 5. Company training policies

\begin{tabular}{lcccc}
\hline & $\begin{array}{c}\text { Yes } \\
(\%)\end{array}$ & $\begin{array}{c}\text { No } \\
(\%)\end{array}$ & $\begin{array}{c}\text { Uncertain } \\
(\%)\end{array}$ & $\begin{array}{c}\text { Total } \\
(\%)\end{array}$ \\
\hline $\begin{array}{l}\text { Company allows apprentice to perform tasks in real operation same as } \\
\text { permanent worker }\end{array}$ & 72.1 & 17.8 & 10.2 & 100.1 \\
Company participate in the NDTS program & 4.4 & 82.2 & 13.4 & 100.0 \\
Company view on staff development as important to company success & 88.0 & 3.3 & 8.7 & 100.0 \\
Company encourage employee to study and increase self-ability & 86.9 & 4.3 & 8.8 & 100.0 \\
Company mission statement emphasize on employee development & 73.5 & 9.9 & 16.7 & 100.1 \\
$\begin{array}{l}\text { Company human resource development policies contribute to company } \\
\text { strategic technological success }\end{array}$ & 52.7 & 30.2 & 17.1 & 100.0 \\
Company have a human resource development plan & 56.3 & 35.5 & 8.2 & 100.0 \\
\hline
\end{tabular}

Referring to Table 6 , only $13.9 \%$ of the respondents said that their companies were invited and $12.9 \%$ of them had attended NTDS seminars and programmes. In summary, this survey results shows that less than $15 \%$ of respondents knew about NTDS seminars and programmes. The rest, more than $85 \%$ were unaware of NTDS seminar or programmes.

Table 6. NDTS awareness

\begin{tabular}{lcccc}
\hline & Yes & No & Uncertain & $\begin{array}{c}\text { Total } \\
(\mathbf{\%})\end{array}$ \\
\hline Company are invited to attend any seminar/programme on NDTS & 13.9 & 71.5 & 14.6 & 100 \\
Company attending any seminar/programme on NDTS & 12.9 & 76.2 & 10.9 & 100
\end{tabular}

The survey respondents (i.e. employers) had given their written comments in the survey questionnaire form. Majority of them said that they do not understand and familiar with NDTS program; hence, result in their lack of participation. The common reasons given were: "never heard", "no information", "not clear about NDTS", "do not know about NDTS", "not aware", "not interested", "not ready yet", "so far we are not familiar with NDTS", "do not know what is NDTS", "in general not many members of the industry know or have adequate information with respect to NDTS". Survey findings shows the two main reasons for employers' lack of awareness with respect to NDTS program are: Department of Skill Development did not invite them to attend any seminars or publicity programs with respect to NDTS (71.5\%); they did not have any NDTS program information or publicity materials $(74.9 \%)$ and therefore they face lack of understanding about NDTS (65.6\%).

\section{Conclusions}

Success of an apprenticeship program is closely related to industrial employers' participation and commitment. Without industrial employers' participation, the concept of duality will not exist. In Malaysia, employers' participation in the NDTS apprenticeship programme is based on voluntary nature. As a result of this policy, the Department of Skills Development need to put extra effort in persuading, convincing and also provide financial incentives to employers that participate in NDTS programme for their human resource development. This can be done by publicity through printed and online media, explaining the benefits and advantages that employers could gain by participating in NDTS apprenticeship programme. It can be seen from the survey results and discussions that employers strongly believed in providing their staff with the appropriate skill training as a strategic factor for improving their product quality, productivity and competitiveness in the market place. In addition, they also perceived training as a crucial factor for developing high skilled and knowledgeable employees that could help them satisfy their customers' needs and requirements. Majority of industrial employers had reported the lack of sufficient information, lack of facilities and suitable mentors or supervisors to conduct training at their workplaces as the three main reasons; why they did not participated in the NDTS apprenticeship program. This is true because in majority of the employers companies that took part in the survey reported that their supervisors were very busy with their daily tasks, such as: giving work orders, checking and coordinating work plans, teaching working method, providing work procedures and initiate, operate, terminate \& monitor system operation. It is suggested that Department of Skills Development to increase employers' awareness and information on NDTS program by advertising their NDTS programs and activities in local newspapers, performing road shows, internet and TV programs. In conclusion, result from this survey can assist Department 
of Skills Development, Ministry of Human Resource in their planning to further improve industrial sectors participation in the NDTS program and thus able to assist them to fulfil market requirement and needs of skilled workers.

\section{Acknowledgements}

The authors are indebted to Universiti Kebangsaan Malaysia for providing financial support through OUP-2012-126 in conducting the survey. This work supported by the Centre for Engineering Education Research, Faculty of Engineering and Built Environment, Universiti Kebangsaan Malaysia, Bangi, Selangor, Malaysia.

\section{References}

Deissinger, T. (1996). Germany's Vocational Training Act: Its function as an instrument of quality control within a tradition-based vocational training system. Oxford Review of Education, 22(3), 317-336. http://dx.doi.org/10.1080/0305498960220305

Deissinger, T. (1997). The German dual system - a model for Europe? Education \& Training, 39(8), 297-302. http://dx.doi.org/10.1108/00400919710190090

Deissinger, T. (2000). The German Philosophy of linking academic and work-based learning in higher education The case of the vocational academies. Journal of Vocational Education and Training, 52(4), 609-630.

Deissinger, T. (2001). Vocational training in small firms in Germany: the contribution of the craft sector. Education \& Training, 43(8-9), 426-436. http://dx.doi.org/10.1108/00400910110411044

Deissinger, T. (2007). Making schools practical: Practice firms and their function in the full-time vocational school system in Germany. Education \& Training, 49(5), 364-379. http://dx.doi.org/10.1108/00400910710762931

Deissinger, T., \& Hellwig, S. (2005). Apprenticeships in Germany: Modernising the dual system. Education \& Training, 47(4-5), 312-324. http://dx.doi.org/10.1108/00400910510601896

Deissinger, T., Heine, R., \& Ott, M. (2011). The dominance of apprenticeships in the German VET system and its implications for Europeanisation: a comparative view in the context of the EQF and the European LLL strategy. Journal of Vocational Education \& Training, 63(3), 397-416. http://dx.doi.org/10.1080/13636820.2011.569089

Department for Skill Development. (2007). Briefing for National Dual Training Systems, Putrajaya, Ministry of Human Resources, Malaysia.

Department for Skill Development. (2008a). Master Plan for Training and Work Skill Development in Malaysia 2008-2020: Skill workers are drivers for Malaysian global competitiveness , Putrajaya, Ministry of Human Resources, Malaysia.

Department for Skill Development. (2008b). Curriculum Registration- National Dual Training Systems (K-NDTS), Putrajaya, Ministry of Human Resources, Malaysia.

Department for Skill Development. (2009). Q- Fact: Implementation Statistics - National Dual Training Systems (K-NDTS), up to $30^{\text {th }}$ 2009, Putrajaya, Ministry of Human Resources, Malaysia.

Department of Statistics. (2008). Workforce Statistics 2008, Economic Planning Unit (EPU): Prime Minister Department, Malaysia.

Fong, C. O. (1986). New Economic Dynamo: Structures and Investment Opportunities in the Malaysian Economy. Sydney: Allen and Unwin.

Glover, R. W., \& Bilginsoy, C. (2005). Registered apprenticeship training in US construction industry. Education \& Training, 47(4-5), 337-349. http://dx.doi.org/10.1108/00400910510601913

Krejcie, R. V., \& Morgan, D. W. (1970). Determining sample size for research. Educational and Psychological Measurement, 60, 607-610.

Liepman, K. (1960). Apprenticeship: An Enquiry into Its Adequacy under Modern Conditions. London: Rutledge and Kegan Paul.

Othman, A. B. (1992). The Development of Technical Training in Malaysia. Master of Education Thesis, La Trobe University, Melbourne Australia. 
Pilz, M. (2007). Two countries - one system of vocational education? A comparison of the apprenticeship reform in the commercial sector in Switzerland and Germany. A Journal of Comparative and International Education, 37(1), 69-87. http://dx.doi.org/10.1080/03057920601061802

Schmidt, H., \& Alex, L. (1997). The Dual System of Vocational Education and Training in Germany. In Roderick Millar, \& Jonathan Reuvid (Eds.), Doing Business with Germany. London.

Smith, W. J. (1997). Trends in Atlanta's Employment Profile. Research Atlanta, Inc., Report Seies, Contributions to Practice.

Steedman, H. (1998). A Decade of Skill Formation in Britain and Germany. Journal of Education and Work, 11(1), 77-94. http://dx.doi.org/10.1080/1363908980110105

Stockmann, R. (1997). An impact assessment of German Vocational-Training Projects in Latin America. World Development, 25(11), 1767-1784. http://dx.doi.org/10.1016/S0305-750X(97)00067-3

Uma, S. (2000). Research Method for Business (3rd ed.). New York: John Wiley \& Son Inc.

Wan Seman, W. A. (2007). To Inculcate Training Culture Amongst Malaysian Industry Through National Dual Training System (NDTS). Putrajaya: Kementerian Sumber Manusia Malaysia. 